\title{
The Effect of Virtual Laboratory Application of Problem-Based Learning Model to Improve Science Literacy and Problem-Solving Skills
}

\author{
Supahar ${ }^{1}$ and E. Widodo ${ }^{1}$ \\ ${ }^{1}$ Department of Physics Education, Faculty Mathematic and Natural Science, Universitas Negeri Yogyakarta \\ Jl. Kolombo 1, Daerah Istimewa Yogyakarta \\ ${ }^{*}$ Corresponding author. Email: supahar@uny.ac.id
}

\begin{abstract}
This research aims at analysing the effect of the Virtual Laboratory (VL) to improve science literacy and problemsolving skills among junior high school students. This research employed a Quasi-experiment with Nonequivalent Control Group Design. The population in this research was the seventh-grade students of junior high school in the Special Region of Yogyakarta in the academic year of 2019/2020. The sample was selected through a cluster random sampling technique and taken the control and the experimental class comprehensively from three school clusters (high, medium, and low) in each district/ city. The data analysis technique used the N-Gain analysis, prerequisite test, and hypothesis testing consisting of MANOVA and effect size. Based on the MANOVA test, it was found that there was a difference in the escalation of students' scientific literacy and problem-solving skills between the control and the experimental class. Meanwhile, based on the calculation of the effect size, it was found that the effect of the Virtual Laboratory was quite high (effect size $=0.897$ ) on the increase in scientific literacy and high effect (effect size $=1.027$ ) on the increase of problem-solving skills, respectively, among junior high school students.
\end{abstract}

Keywords: virtual laboratory, problem-based learning, literacy, problem-solving skills.

\section{INTRODUCTION}

The current condition of the Covid-19 pandemic has changed learning environments that place more emphasis on distance learning or online method. It urges teachers to improve their technological skills in learning and learning media making [1]. Virtual laboratory (VL) learning is one of the main elements that is very influential in the current educational system [2] and getting more popular as a form of high-tech application in the learning process [3]. This model is also suitable to promote the use of technology in the classroom [4].

The utilization of information technology as learning media must be directed to develop the students' potential, especially to face future challenges, like scientific literacy and problem-solving skills. Science literacy refers to the ability to be involved in science issues [5], while problem-solving skills are the basic skills in resolving a problem that needs critical, logical, and systematic thinking. The use of the VL of problem-based learning (PBL) will be beneficial to improve students' scientific literacy and problem-solving skills simultaneously. PBL according to [6] is a learning model that aims to help students to learn and find concepts and solve problems by connecting problem situations in the real world. The purpose of PBL is also to help students in developing their thinking skills, problem-solving, and intellectual skills [7]. Similarly, Bahri, et al. [8] explain that PBL can train and improve students' ability to solve problems, communicate, collaborate, and solve various problems from different perspectives. The Virtual Laboratory of PBL model must be put forward because the biggest problem that hinders science learning is laboratory practical activities that online.

Scientific literate society is an ideal condition to answer and deal with global issues in the 21 st century. Students as part of the community need to be trained to have science literacy and it will be a reflection of the science learning goals ([9], [10]). International surveys related to scientific literacy are annually done by the Organization for Economic Cooperation and Development (OECD) to assess the extent to which the schools prepare their students in science learning. The OECD is an institution that conducts research focusing 
on reading skills, mathematics, and scientific literacy or known as the PISA test. PISA is considered as an international standard instrument to assess the students' ability to face real-life [11].

The results of the 2018 PISA of Indonesia are decreasing compared to 2015 ([11], [12]) with a score of 396 (OECD average was 489) (OECD, 2019b). The 2018 PISA requires students to be able to plan and do based on their plan as well as solve problems with their peers in groups ([11], [12]). This fact can be an indicator that Indonesian students still lack scientific literacy skills, and it becomes a big challenge for the government, teachers, and researchers to work harder to improve the students' performance in the following PISA tests.

Based on level 7 in the OECD document [13], the current Indonesian score is at level 1a where students can only use basic and procedural knowledge to recognize or identify explanations of simple scientific phenomena. From the 2018 PISA results, 2 provinces in Indonesia had a higher score of scientific literacy than the average score of Indonesia, i.e. Jakarta (score 424) and Yogyakarta (score 434). However, those scores are still at level 2 where students can only recognize correct explanations for known scientific phenomena and use that knowledge to identify simple cases without any judgment of the valid conclusions from the provided data.

In addition to realize science-literate society, science learning also emphasizes students thinking skills to be able to master and solve problems critically, logically, carefully and thoroughly so that they do not only understand concepts [14] but also know how to apply the relevance of science learning to everyday life and social problems ([15], [16]). Problem solving skills are important for students, because each individual is always faced with various problems that must be solved through creativity to find solutions [17]. Geege Polya (in [18]), revealed that problem solving skills include the following skills: understanding problems, compiling problemsolving plans, implementing problem-solving plans, and re-checking the results obtained. Problem solving skills can train students to find various concepts in a holistic, meaningful, authentic, and applicable manner [19].

$$
<G>=\frac{<\% \text { post }>-<\% \text { pre }>}{100 \%-<\% \text { pre }>}
$$

where $\langle\mathrm{G}\rangle=$ average normalized gain, $\langle \%$ post $\rangle=$ percentage of average Posttest score, $\langle \%$ pre $\rangle=$ percentage of average Pretest value, $100 \%=$ maximum
The use of the VL of PBL model as an online practicum can provide an experience of the scientific working process in the laboratory as a substitute for real learning settings to improve students' scientific literacy and problem-solving skills. Based on these descriptions, the researcher plans to examine the effect of the virtual laboratory of the PBL model to enhance science literacy and problem-solving skills among junior high school students.

\section{METHODS}

The research design used quasi-experiment with Nonequivalent Control Group Design. The population of this study came from grade VII junior high school students in the Special Region of Yogyakarta in the 2019/2020 school year. Sampling was done by using cluster random sampling technique by taking control class and experimental class from three school clusters (high, medium, and low) in each district / city. This study used a non-equivalent control group design as presented in Table 1 below.

Table 1. Research Design

\begin{tabular}{lccc}
\hline \multicolumn{1}{c}{ Group } & Pretest & Treatment & Posttest \\
\hline Experiment & O1 & VL-PBL & O3 \\
Group & O1 & & O3 \\
\hline Control & O2, & DI & O4 \\
Group & O2 & & O4 \\
\hline
\end{tabular}

Explanation:

VL-PBL = Treatment with the use of the VL of the PBL model

DI $=$ Treatment with Direct Learning (DL)

$\mathrm{O} 1=$ Science Literacy Pretest

$\mathrm{O} 2$ = Problem Solving Skills Pretest

O3 = Science Literacy Posttest

O4 = Posttest Problem Solving Skills

The data collected included students' scientific literacy and problem-solving skills through the results of the pretest-posttest. After the pretest-posttest data was obtained, the N-Gain score $(<G\rangle)$ was calculated using the following formula.

score. The results of the $\langle\mathrm{G}\rangle$ calculation are interpreted with the following classification.

Table 2. Interpretation of the N-gain value

\begin{tabular}{cl}
\hline Value $<\mathrm{G}>$ & Interpretation \\
\hline$-1.00 \leq G<0.00$ & There was a decline \\
$\mathrm{G}=0.00$ & There was no decline \\
$0.7<G<1$ & High \\
$0.3 \leq G \leq 0.7$ & Moderate
\end{tabular}


The size effect value obtained from the N-Gain value $(<G\rangle)$ was tested for statistical prerequisites including the normality test (Kolmogorov Smirnov) and homogeneity (Levene's Test of Equality of Error Variances). Then proceed with hypothesis testing by means of the MANOVA test on the N-Gain score and the calculation of the size effect using the formula below.

$$
d=\frac{\bar{x}_{1}-\bar{x}_{2}}{S_{g a b}}
$$

with

$$
S_{g a b}=\sqrt{\frac{\left(n_{1}-1\right) S_{1}^{2}+\left(n_{2}-1\right) S_{2}^{2}}{n_{1}+n_{2}-2}}
$$

Explanation:

$\mathrm{d}=$ magnitude of effect size

$\bar{x}_{1}=$ average of experiment group

$\bar{x}_{2}=$ average of control group

$S_{g a b}=$ combined standard deviation

$n_{1}=$ number of students in experimental group $n_{2}=$ number of students in contol group

$S_{1}^{2}=$ variance of experimental group

$S_{2}^{2}=$ variance of control group

The Size Effect interpretation can be explained as in Table 3 below.

\section{RESULT AND DISCUSSIONS}

3.1. Measurement Results on Science Literacy and Problem-Solving Skills

This study aims at analyzing the effect of the VL of the PBL model application to enhance science literacy and problem-solving skills among junior high school students. The obtained data in this study were from the posttest results in science literacy and problem-solving skills. The posttest results for the experimental class (VLPBL) and the control class (Direct Learning/ DL) is presented in Figure 1 below.

Table 3. Size Effect Interpretation

\begin{tabular}{cc}
\hline Size Effect & Category \\
\hline $0-0.5$ & Low \\
$0.6-0.8$ & Quite High \\
$0.9-3$ & High \\
\hline
\end{tabular}

It can be seen from Figure 1 that the posttest scores of scientific literacy and problem-solving skills in the experimental class were higher than the control class because of the application of the VL of PBL model place problems as the starting point. By having this condition, students can learn and try to find solutions to the problems that develop their thinking skills and problemsolving abilities [21]. The nature of the VL of PBL is a learning process that employs authentic problems to be solved. The authentic problems in online learning were designed in the form of a virtual practicum as in this study. The adjustment of the practicum simulation with the real context through VL can accelerate students' understanding by challenging students' creativity during the learning process [22].

In some studies, VL was used for chemical and physical simulations due to safety issues, psychological factors, time, and energy for conducting the real practicum ([23], [24], [25], [26]). VL can be used as an alternative learning medium in solving educational problems that are given to students ([27], [28]). Interactive learning through $\mathrm{VL}$ also helps students to solve concepts with abstract materials topics. It makes students more active during their learning process and allows them to construct, and understand difficult concepts [29]. The developed VL design provides opportunities for students to express their cognitive styles, for example, they can provide hypotheses on a certain topic and propose solutions in that aspect [30].

The results of this study were also strengthened by the results of the N-Gain calculation which showed the escalation of science literacy and problem-solving skills as shown in Figure 2 below. 


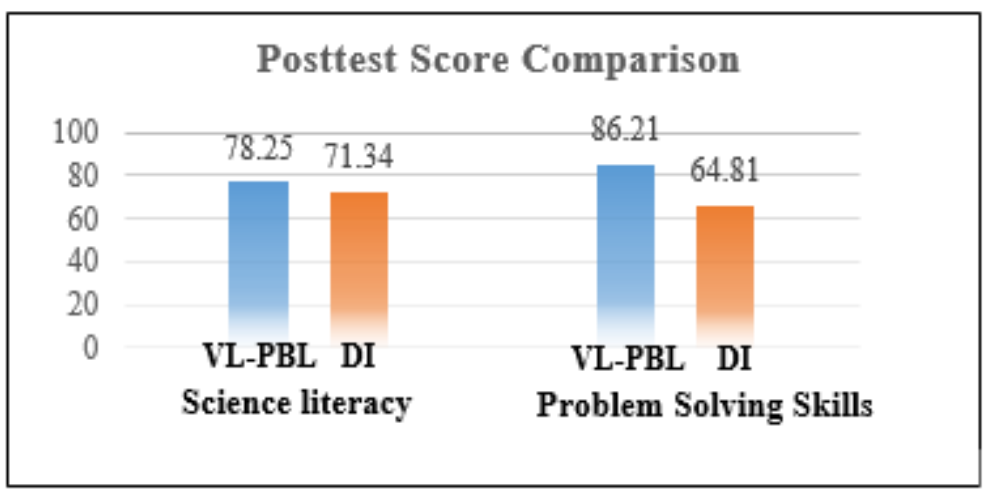

Figure 1. Posttest Score Comparison in the Experiment Class and the Control Class

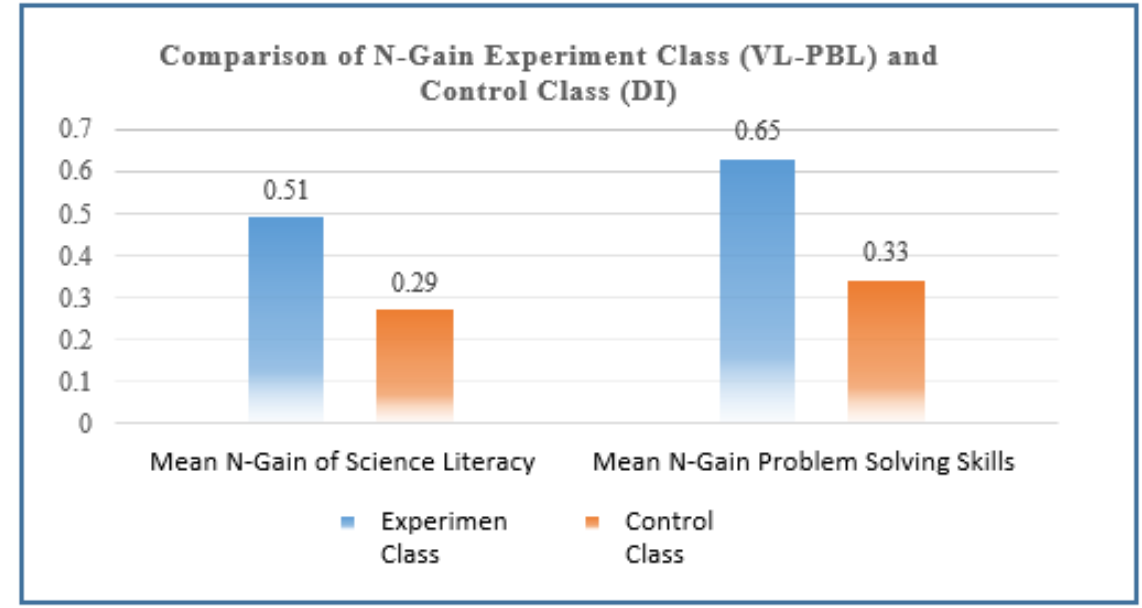

Figure 2. N-Gain Comparison of Science Literacy and Problem-Solving Skills

It can be seen in Figure 2 that the $\mathrm{N}$-Gain score of the experimental class was higher than the control class. For scientific literacy, the experimental class had the N-Gain score of 0.51 (moderate category), while the control class gained the $\mathrm{N}$-Gain score of 0.29 (low category), respectively. Meanwhile, the experimental class obtained the $\mathrm{N}$-Gain score of 0.65 (moderate category) for problem-solving and the control class was 0.33 (moderate category), respectively.

The difference in the escalation of science literacy has proven that the VL of PBL in this study can assist the students to develop critical thinking skills through practicum simulations that are exactly the same as the real settings. It is similar with the findings of some studies that practicum simulation with computers is more effective than the traditional one ([31], [29]), though other studies have also found that there is no difference related to its effectiveness ([32], [33], [34]).
3.2. The Influence of VL PBL Model on Science Literacy and Problem-Solving Skills

The effect of the VL of the PBL model to enhance science literacy and problem solving-skills among junior high school students was analyzed using the MANOVA test (Multivariate test). This test showed the sig.value of 0.008 which was smaller or less than the significance level of $0.05(\alpha=5 \%)$, so Ha was accepted (H0 was rejected). It means that there is a difference in the escalation of science literacy and problem-solving skills between the experimental class with the developed VL of the PBL model and the control class with Direct Learning. In other words, learning using VL of PBL enhance science literacy and problem-solving skills among junior high school students.

One-Way MANOVA test on posttest data was done to determine differences in problem-solving skills and science literacy among junior high school students in the experimental and the control class after the given treatment. The results of the multivariate tests on the posttest data are shown in Table 4 below. 
Table 4. Results of Multivariate Tests

\begin{tabular}{llccccc}
\hline Effect & Value & F & Hypothesis df & Error df & Sig. \\
\hline Intercept & Pillai's Trace & .882 & $3548.084^{\mathrm{b}}$ & 2.000 & 53.000 & .003 \\
\cline { 2 - 7 } & Wilks' Lambda & .038 & $3548.084^{\mathrm{b}}$ & 2.000 & 53.000 & .000 \\
\cline { 2 - 7 } & Hotelling's Trace & 44.252 & $3548.084^{\mathrm{b}}$ & 2.000 & 53.000 & .002 \\
\cline { 2 - 7 } Class & Roy's Largest Root & 44.252 & $3548.084^{\mathrm{b}}$ & 2.000 & 53.000 & .000 \\
\cline { 2 - 7 } & Pillai's Trace & .222 & $34.443^{\mathrm{b}}$ & 2.000 & 53.000 & .002 \\
\cline { 2 - 7 } & Wilks' Lambda & .588 & $34.443^{\mathrm{b}}$ & 2.000 & 53.000 & .002 \\
\cline { 2 - 7 } & Hotelling's Trace & .488 & $34.443^{\mathrm{b}}$ & 2.000 & 53.000 & .000 \\
\cline { 2 - 7 } & Roy's Largest Root & .488 & $34.443^{\mathrm{b}}$ & 2.000 & 53.000 & .002 \\
\hline
\end{tabular}

The results of the multivariate tests above can be used to answer the previous hypotheses. The obtained Sig.value at most 0.002 in the Hotelling's Trace test indicated that the value was lower than 0.05 , so $\mathrm{H} 0$ was rejected, and Ha was accepted. This means "there are differences in problem-solving skills and science literacy among junior high school students between the experimental class and the control class". These results indicate that after the treatments were given in each class, problem-solving skills, and science literacy, there was simultaneously a gap between the experimental class and the control class. The next output was the test of between-subjects effects to examine the effect of univariate ANOVA for each factor on the dependent variable as shown in the following Table 5.

Table 5. Test of Between-Subjects Effects

\begin{tabular}{|c|c|c|c|c|c|c|}
\hline Source & $\begin{array}{c}\text { Dependent } \\
\text { Variable }\end{array}$ & $\begin{array}{l}\text { Type III Sum of } \\
\text { Squares }\end{array}$ & df & Mean Square & $\mathbf{F}$ & Sig. \\
\hline \multirow{2}{*}{$\begin{array}{l}\text { Corrected } \\
\text { Model }\end{array}$} & Science literacy & $252.832^{\mathrm{a}}$ & 3 & 252.832 & 8.522 & .008 \\
\hline & $\overline{\mathrm{GSS}}$ & $2232.828^{b}$ & 3 & 2232.828 & 28.585 & .000 \\
\hline \multirow{2}{*}{ Intercept } & Science literacy & 388580.855 & 3 & 388580.855 & 2883.522 & .002 \\
\hline & GSS & 388202.285 & 3 & 388202.285 & 3332.520 & .004 \\
\hline \multirow{2}{*}{ Group } & Science literacy & 252.832 & 3 & 252.832 & 8.522 & .008 \\
\hline & GSS & 2232.828 & 3 & 2232.828 & 28.585 & .000 \\
\hline \multirow{2}{*}{ Error } & Science literacy & 2822.522 & 52 & 50.225 & & \\
\hline & GSS & 8823.200 & 52 & 350.022 & & \\
\hline \multirow{2}{*}{ Total } & Science literacy & 382888.222 & 52 & & & \\
\hline & $\overline{\mathrm{GSS}}$ & 382528.525 & 52 & & & \\
\hline \multirow{2}{*}{$\begin{array}{l}\text { Corrected } \\
\text { Total }\end{array}$} & Science literacy & 2388.258 & 52 & & & \\
\hline & $\overline{\mathrm{GSS}}$ & 32222.228 & 52 & & & \\
\hline
\end{tabular}

The analysis results showed that the dependent variable of science literacy had sig value at most 0.008 which was less than 0.05 . This means that there is a significant difference in science literacy among junior high school students between the experimental class and the control class after the given treatment. The dependent variable of problem-solving skills obtained sig value. at most 0.004 which was less than 0.05 . It indicates that there is a significant difference in problem-solving skills between the control class and the experimental class after the treatment.
These results are consistent with the research [21] that proves that the application of Problem Based Learning (PBL) is effective in increasing the students' problemsolving abilities. It is supported by a claim [35] that the application of PBL can build students' scientific literacy. According to Diana et al. [36], teachers are encouraged to introduce contextual materials by using various strategies that can train scientific literacy skills including teaching material through experiments that can stimulate higher-order thinking.

In the developed VL of the PBL model, the students performed a problem solving-based investigative 
practicum with the problem identification around students' life and problem formulation at the beginning. According to Sutarno et al. [37], the application of problem solving-based practicum can train higher-order thinking skills. The VL of the PBL model also presents real-life problems for students to train their critical thinking and problem-solving skills as well as to acquire knowledge and concepts [7]. Thus, the VL of the PBL model is suitable to enhance students' scientific literacy because it is contextual and can stimulate students' higher-order thinking skills.

PBL model places problems as stimuli for the students' learning activities to optimally develop their problem-solving skills in everyday life. It agrees with the goals [38] that education should enable individuals to gain problem-solving skills and train individuals to overcome problems in their real life. In addition to training and improving students' abilities in problemsolving, PBL also improves communication and collaboration skills. [8]. So, it is clear that the VL of the PBL model is beneficial to enhance students' science literacy and problem-solving skills

The analysis of the effect size was then performed to know the extent to which the influence of the VL of the PBL model on each variable. The results gained the value of 0.897 (quite high category) for the effect of the virtual laboratory on the scientific literacy, and the value of 1.027 (high category) for the effect on students' problemsolving skills, respectively. It means that the VL of the PBL model can enhance students' scientific literacy and problem-solving skills.

\section{CONCLUSION}

Based on the research results and discussion, it can be concluded that there is a positive effect on the application of Virtual Laboratory of Problem Based Learning (VL of PBL) Model to improve scientific literacy and problemsolving skills among junior high school students that can be seen from the analysis results of MANOVA (Multivariate Test) with Sig.value $(0.002)<\alpha(0.05)$. It indicates that $\mathrm{HO}$ is rejected ( $\mathrm{Ha}$ is accepted). Moreover, the calculation of the effect size found that the VL of the PBL model was quite high (effect size $=0.897$ ) on the escalation of scientific literacy, while problem-solving skills were high (effect size $=1.027$ ).

\section{ACKNOWLEDGMENTS}

We would like to thank the Directorate of Research and Community Service, Directorate General of Higher Education, Ministry of Education and Culture and Institute and also The Institute of Research and Community Service, Universitas Negeri Yogyakarta for their financial support and management assistance on this research project.

\section{REFERENCES}

[1] McGarr, O. (2020). The use of virtual simulations in teacher education to develop pre-service teachers' behavior and classroom management skills: implications for reflective practice. Journal of Education for Teaching, 00(00), 1-11. https://doi.org/10.1080/02607476.2020.1724654

[2] Winkelmann, K., Keeney-Kennicutt, W., Fowler, D., Lazo Macik, M., Perez Guarda, P., \& Ahlborn, C. J. (2019). Learning gains and attitudes of students performing chemistry experiments in an immersive virtual world. Interactive Learning Environments, $0(0)$, $1-15$. https://doi.org/10.1080/10494820.2019.1696844

[3] Bautista, N. U., \& Boone, W. J. (2015). Exploring the Impact of TeachMETM Lab Virtual Classroom Teaching Simulation on Early Childhood Education Majors' Self-Efficacy Beliefs. Journal of Science Teacher Education, 26(3), 237-262. https://doi.org/10.1007/s10972-014-9418-8

[4] Ahmed, M. E. (2014). an Instructional Design Model and Criteria for Designing and Developing Online Virtual Labs. International Journal of Digital Information and Wireless Communications, 4(3), 355-371. https://doi.org/10.17781/p001289

[5] OECD. (2019a). PISA 2018 Science Framework, in PISA 2018 Assessment and Analytical Framework. Paris: OECD Publishing, Retrieved January 2, 2020, from https://doi.org/10.1787/b25efab8-en.

[6] Wisudawati, A. W., \& Eka, S. (2014). Metodologi Pembelajaran IPA: Disesuaikan dengan Kurikulum 2013. Jakarta: Bumi Aksara.

[7] Cahyani, H., \& Setyawati, R. W. (2016). Pentingnya Peningkatan Kemampuan Pemecahan Masalah melalui PBL untuk Mempersiapkan Generasi Unggul Menghadapi MEA. In Seminar Nasional Matematika X UNNES (pp. 151-160). Semarang.

[8] Bahri, A., Putriana, D., \& Idris, I. S. (2018). Peran PBL dalam Meningkatkan Keterampilan Pemecahan Masalah Biologi The Role of PBL in Improving Biological Problem-Solving Skill. Jurnal Sainsmat, VII(2), 114-124.

[9] Drummond, C., \& Fischhoff, B. (2017). Individuals with greater science literacy and education have more polarized beliefs on controversial science topics. Proceedings of the National Academy of Sciences of the United States of America, 114(36), 9587-9592. https://doi.org/10.1073/pnas.1704882114

[10] Tytler, R., Prain, V., \& Peterson, S. H. (2006). Picturing evaporation: learning Science literacy 
through a particle representation. Teaching Science : The Journal of the Australian Science Teachers Association, 52(1), 12-17.

[11] Sälzer, C. (2018). International Journal of Development Education and Global Learning Assessing global competence in PISA 2018: Challenges and approaches to capturing a complex construct. International Journal of Development Education and Global Learning, 10(1), 6-20. https://doi.org/10.18546/IJDEGL.10.1.02

[12] Tohir, M. (2019). Hasil PISA Indonesia Tahun 2018 Turun Dibanding Tahun 2015. Paper of Matematohir, 2(1), 1-2. Retrieved from https://matematohir.wordpress.com/2019/12/03/has il-pisa-indonesia-tahun-2018-turun-dibandingtahun-2015/

[13] OECD. (2016), PISA 2015 Results (Volume I): Excellence and Equity in Education, PISA, OECD Publishing, Paris, http://dx.doi.org/10.1787/9789264266490-en

[14] Darwanti, A. (2013). Upaya Peningkatan Hasil Belajar Ipa Dengan Creative Approach Berbasis Pictorial Riddle Approach Pada Siswa Kelas V Sdn 03 Karangsari Jatiyoso Tahun Pelajaran 2012/2013. Universitas Muhammadiyah Surakarta.

[15] Asrizal, Amran, A., Ananda, A., Festiyed, F., \& Khairani, S. (2018). Effectiveness of integrated science instructional material on pressure in daily life theme to improve digital age literacy of students. Journal of Physics: Conference Series, 1006(1), 17. https://doi.org/10.1088/17426596/1006/1/012031

[16] Holbrook, J., \& Rannikmae, M. (2009). The Meaning of Scientific Literacy. International Journal of Environmental \& Science Education, 4(3), 275-288. https://doi.org/10.1097/00006199195402000-00010

[17] Permatasari, N. Y., \& Margana, A. (2014). Meningkatkan Kemampuan Siswa Dalam Memecahkan Masalah Matematika Dengan Model Pembelajaran Treffinger. Jurnal Pendidikan Matematika, 3(1), 31-42.

[18] Tambunan, H. (2014). Strategi Heuristik dalam Pemecahan Masalah Matematika Sekolah. Jurnal Saintech, 6(4), 35-40.

[19] Hariawan, Kamaluddin, \& Wahyono, U. (2013). Pengaruh model pembelajaran creative problem solving terhadap kemampuan memecahkan masalah fisika pada siswa kelas XI SMA Negeri 4 Palu. Jurnal Pendidikan Fisika Tadulako (JPFT), 1(2), 48-54.
[20] Becker, L.A., (2000). Effect Size (ES). Journal: Effect Size Measures for Two Independent Groups. Retrieved January 6, 2020, from http;//web.uccs.edu/lbecker/Psy590/es.html.

[21] Lismayani, I., \& Mahanal, S. (2017). Efektivitas Problem Based Learning (PBL) Dalam Meningkatkan Kemampuan Pemecahan Masalah. In Prosiding TEP \& PDs: Transformasi Pendidikan Abad 21 (pp. 737-748).

[22] Herga, N. R., Čagran, B., \& Dinevski, D. (2016). Virtual Laboratory in the Role of Dynamic Visualisation for Better Understanding of Chemistry in Primary School. Eurasia Journal of Mathematics, Science \& Technology Education, 12(3), 593-608.

[23] Tatli, Z. \& Ayas, A. 2010. Virtual laboratory applications in chemistry education. Procedia Social and Behavioral Sciences, 9, 938-942. DOI: 10.1016/j.sbspro.2010.12.263.

[24] Bryant, R. J., \& Edmunt, A. M. (1987). They like lab-centered science. The Science Teacher, 54(8), $42-45$.

[25] Hofstein, A., \& Lunetta, V. (2003). The Laboratory in science education: Foundation for the $21 \mathrm{st}$ century. Journal of Science Education, 88(1), 28-54

[26] Durmus, J., \& Bayraktar, S. (2010). Effects of conceptual change texts and laboratory experiments on fourth-grade students' understanding of matter and change concepts. Journal of Science Education and Technology, 19(5), 498-504.

[27] Kumar, A., Pakala, R., Ragade, R. K., \& Wong, J. P. (1998). The virtual learning environment system. Paper presented at the IEEE Computer Society, FIE Conference, CA, USA

[28] Shin, D., Yoon, E.S., Park, S.J., \& Lee, E.S. (2000). Web-based interactive virtual laboratory system for unit operations and process systems engineering education. Computers and Chemical Engineering, $24,1381-1385$.

[29] Martinez-Jimenez, P., Pontes-Pedrajas, A., Polo, J. \& Climent-Bellido, M.S. (2003). Learning in Chemistry with Virtual Laboratories. Journal of Chemical Education, 80(3), 346. Retrieved August 8, 2020, from https://www.learntechlib.org/p/95042/.

[30] Domingues, L., Rocha, I, Dourado, F., Alves, M \& Ferreira, E.C. 2010. Virtual laboratories in (bio) chemical engineering education. Journal Education for Chemical Engineers 5 (2010):e22-227. Online at www.elsevier.com. [retrieved on 2 January 2011]. 
[31] Flowers, L. O. (2011). Investigating the effectiveness of virtual laboratories in an undergraduate biology course. The Journal of Human Resource and Adult Learning, Vol. 7 No.2, page. 110-116.

[32] Miller, D.G. (1986). The Integration of Computer Simulation into the Community College General Biology Laboratory. Dissertation Abstract International, 47(6), 2106-2115.

[33] Choi, B. \& Gennaro, E. (1987). The Effectiveness of Using Computer Simulated Experiments on Junior High Students' Understanding of The Volume Displacement Concept. Journal of Research in Science Teaching, 24, 539-552.

[34] Bayrak, B., Kanlı, U \& Kandil İngeç, Ş. (2007). To Compare The Effects Of Computer-Based Learning And The Laboratory-Based Learning On Students' Achievement Regarding Electric Circuits. The Turkish Online Journal of Educational Technology, 6(1), 15-24

[35] Ardianto, D., \& Rubini, B. (2016). Comparison of Students' Scientific Literacy in Integrated Science
Learning Through Model of Guided Discovery and Problem Based Learning. Jurnal Pendidikan IPA Indonesia, 5(1), 31-37.

[36] Diana, S., Rachmatulloh, A., \& Rahmawati, E.S. (2015). Profil Kemampuan Literasi Sains Siswa SMA Berdasarkan Instrumen Scientific Literacy Assesment (SLA). In Seminar Nasional XII, Pendidikan Biologi FKIP UNS (Vol. 201).

[37] Sutarno, S., Setiawan, A., Kaniawati, I., \& Suhandi, A. (2017). Pre-Service Physics Teachers' ProblemSolving Skills In Projectile Motion Concept. In Journal of Physics: Conference Series, 895(1). IOP Publishing.

[38] Memnun, D.S., et al. (2012). A Research on The Mathematical Problem Solving Belief of Mathematics, Science, and Elementary Pre-Service Teacher in Turkey in Term 78 of Different Variable. International Journal of Humanities and Social Science, 24(2). 